\title{
The Pattern of Trade Flows in Nigeria during the Pre-and Post-Era of Covid-19
}

\author{
Kehinde Mary Bello $^{1^{*}[\mathbb{C}}$, Matthew Oladapo Gidigbi ${ }^{2}$ \\ ${ }^{1}$ Department of Economics, Faculty of Social Sciences, Obafemi Awolowo University, P.M.B. 13, Ile-Ife 220282, Nigeria \\ ${ }^{2}$ Department of Economics, Faculty of Social and Management Sciences, Modibbo Adama University, P.M.B. 2076, Yola 640001, \\ Nigeria \\ E-mail: kennybello2008@gmail.com; kbello@pg-student.oauife.edu.ng
}

Received: 11 May 2021; Revised: 12 January 2022; Accepted: 12 January 2022

\begin{abstract}
Trade can serve as a major transmitter of economic disruption across the globe and a tool for quick recovery in times of crisis. While the pandemic disrupted trade activities globally in global merchandise, the traditional mode shifted grounds to digitalization embracement in trade activities. Therein, the concern that this development may further aggravate the catch-up effect of the developing countries like Nigeria is a serious issue due to their deficient digital technological facilities. Although, ICT industries experienced tremendous growth during and post Covid-19 eras in Nigeria. This paper is a desk review investigation carried out on the methods of trade during the pre-and-post Covid-19 era. The data revealed that there was decrease in trade pattern during and post-era of the Covid-19 pandemic globally and in African countries (Nigeria). It was therefore concluded that unlike the pre-Covid-19 trade experience, there was increasing migration of trade to digital network in the era-and-post-Covid-19 period. The paper thereby recommends digitalization of trade activities in forestalling breakdown of trade activities during the post-pandemic era.
\end{abstract}

Keywords: trade, Covid-19, lockdown, gross domestic product, Nigeria

JEL Code: F1, F13, F19

\section{Introduction}

The outbreak of Covid-19 virus in 2019 put countless numbers of people and businesses at risk. Equally, millions lost their jobs and sources of income. Presently, uncertainty still exists as the number of new cases of the virus is still rising while a second wave is becoming alarming, even with its new variants (Omicron). The endemic had continuously been on the increase and its effect on socio-economic activities and global trade pattern calls for attention (UNCTAD, 2020). Research on economic density has indicated that the export condition of a country lies in the future pattern of trade and economic diversification. Yet, petite emphasis is placed on the inequality allied with the product type traded between different regions and countries in the world. Mostly, the non-parametric analysis revealed that developing countries that are more exposed to trade are prone to more diversified export structures compared to those with closed trade. The economic interruption caused by the pandemic harbored unprecedented disruption in international trade in

Copyright (C2022 Kehinde Mary Bello, et al.

DOI: https://doi.org/10.37256/redr.232021925

This is an open-access article distributed under a CC BY license

(Creative Commons Attribution 4.0 International License)

https://creativecommons.org/licenses/by/4.0/ 
2020. The supply and demand shocks initiated in major economies through various trade channels speedily extended to developing regions. This ended up disproportionately causing negative economic shocks in developing countries. Hitherto, trade played a major role in aiding economic recovery.

It is of the opinion that no country is a highland in the sufficiency of goods and services. Therefore, international trade is of great significance as no country can provide all requirements for the citizens. Therefore, trade is a standard in the world economy as there would always be changes in the trading environment. The changes, however, deals with various challenges and opportunities in formulating appropriate policies (Shuaib, 2020). The measures of lockdown and other business closures implemented by main economies in North America during the pandemic resulted in disruptions in the global market. The demand and supply shocks were rapidly transmitted to developing regions through networks of trade in goods and services. The major sectors like tourism and commodities that are the major source of external earnings in most developed countries were greatly affected.

A massive decline in demand for commodities occurred as a result of standstill in economic activities. This prompted decrease in the export earnings among Latin American and African countries due to sharp decline in commodity prices. The percentage decrease in the UNCTAD Commodity Price Index from a year-on-year perception in 2020 was similar to the drop experienced in 2015 and 2016 (UNCTAD, 2020). Trade statistics beyond 2020 showed an extensive decrease in service trade which accelerated over the medium term. The trend accelerated to structural cross-border trade which increased over the last decade. Presently, service trade had dominated the "traditional form of trade" in terms of travel and transportation services towards computer and information services, financial services, audio-visuals and business services (WTO, 2020). In taking cognizance observations during 2008/2009 Global Financial Crisis (GFC), trade was the first victim in which new trade restriction measures were affected by $1 \%$ of world imports. Consequently, the G20 ascertain their commitment to uphold the rules-based trading system and refrain from protectionist measures.

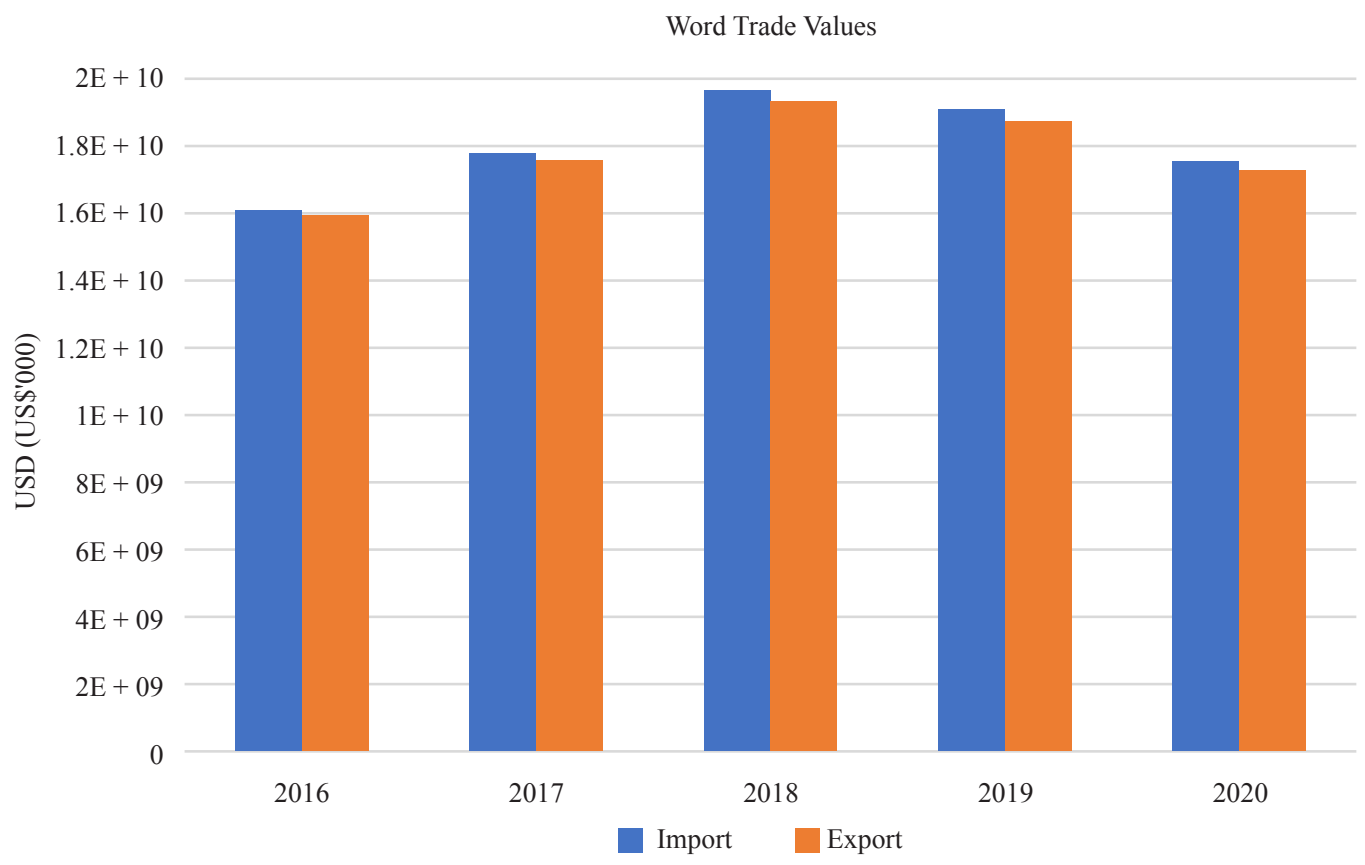

Figure 1. World's Import and Export in Values (US\$'000)

Source: Authors Computation using data from ITC calculations based on UN COMTRADE and ITC statistics (2021)

On another hand, the WTO formed trade rules for stabilizing the system and created certainty for businesses by placing limits on tariff measures. Even though there were some differences and similarities, the current ongoing crisis calls for commitments to rules based on trade (OECD, 2020). Growth in international trade decreased over the past four 
years in the second quarter of 2020, and there was a reduction of $13 \%$ from the preceding quarters. In the recovery stage from second quarter, the data showed that the growth of global trade on a year-on-year basis was steady with a decrease of about $4.5 \%$ as suggested by the data from the third quarter of 2020 (UNCTAD, 2020). Also, evidence from the data presented in Figure 1 above showes that trade value dropped in 2020 with respect to import and export compared to year 2017, 2018 and 2019.

The major objective of this article is to appraise the pattern of trade flows during the pre-and post-era of Covid-19 in Nigeria using descriptive analysis. To accomplish this, the paper is structured as follows: the subsequent section discusses the pattern of trade in Covid-19 era. Then, review of literature and the comparison among the pattern of trade flow in developed, emerging and Africa countries during the pre-and post-era of Covid-19. Afterwards, the changing pattern of international trade was reviewed; and the era of digital economy. Finally, the article evaluated the digital pattern of trade in Nigeria and then the conclusion.

\subsection{The pattern of trade in the era of Covid-19 crisis}

The pandemic struck the world when trade was in a state of great confusion. In 2019, the World Trade declined in all quarters but intensified in early quarter of 2020 as a result of effects on China. There was a drop in China's export by about $21 \%$ as of February 2020. As the pandemic started to hit exports from other countries, export from the United States and Europe declined by 7\% and 8\% respectively. However, export recovered slightly in China in March 2020. But to curtail the virus, most countries ordered lockdown in late March/April 2020 (ITC, 2020). The global shutdown affected the mobility of people and cross-border freight transport services, thereby negatively impacting trade in goods. These disrupted shipping activities with consequences on the variability of supply chain and goods in trade (WTO, 2020). However, there was an increase in demand for personal protective equipment and medical goods like thermometers, protective shield and garments, hand sanitizers and ventilators (United Nations, 2020).

In order to quickly curtail the spread of the virus by ensuring adequate supplies of vital goods for domestic markets, numerous countries had recourse to procure emergency measures by either restricting export of some products or promoting imports by easing non-tariff measures and employing tariff reduction to influence trade flows. Most countries lowered their import barriers by eliminating or reducing tariffs to import essential goods and medical supplies to accelerate import flows. On the contrary, technical procedures such as product safety standards and sanitary, and phytosanitary measures were more effective on trade cost other than tariffs (UNCTAD, 2013). Nevertheless, these measures had their public policy purposes in terms of health and safety protections which could not be merely eliminated. Therefore, the harmful effect of the virus-instigated efforts to enhance regulatory cooperation via mutual harmonization and recognition of standards. Also, in the case of exceptional and normal circumstances, conformity assessment measures were a point of focus (UNCTAD, 2020).

The world's largest supplier of medical equipment; United States, Switzerland, Germany and India imposed export-restricting measures in March and April 2020. This brought about dangerous impact of import-enhancing measures and disrupted import flows. The export-restricting measures which included export licensing requirements, quantitative restrictions and export bans were imposed, supplies were diverted away from the world market and pressure was instigated on international prices (International Trade Center Trade Map, 2020). This affected some other countries which did not have the domestic productive ability for essential goods (OECD, 2020). In other words, the export restriction momentarily increased prices domestically and increased availability. It also diminished consumers trust in firms and international markets in the long run. About 141 countries and territories employed 330 emergency trade measures as of mid-September 2020. Nearly $75 \%$ of these measures had no specified dates for termination while the others were intended to last for over six months on average (International Trade Center Market Access Map: COVID-19 Temporary Trade Measures, 2020).

The prevailing thought and fact in relation to trade from the developed economies, through emerging, lane down to the developing economies are that the disruption in trade activities caused a dip in trade flows in the economy. The magnitude of the dip and aspect of the trade activities affected was a result of the magnitude of the disruption and how it interplayed in local or global economies, as well as the position of the economy, from which the disruption began. The drive here is that the Covid-19 pandemic caused abrupt changes in economic variables at a point in time. This is a proposition that the pandemic has a structural change in effect in the economic variables. It is structural in nature because it was unexpected before the global advent of the pandemic, but with its presence, it became a reality. Many 
factors that could cause a structural break among these was a sudden event like the global lockdown experienced as a result of the Covid-19 pandemic, which greatly affected production and distribution, and large shifts from consumer goods to immediate medical consumables.

Since the pandemic structure and its immediate approach suggested a structural break, we hereby test for a break in a specific date as related to the Covid-19 pandemic in the variables interest. It is under stability that Nigeria earns the bulk of her revenue and/or forex from exportation and at the period of the pandemic, export was greatly dipped due to production shut down in most economies of the world. Although, production of medical supplies was accelerated, the country has little or zero value-chain in the exportation of medical supplies. Therefore, a structural break is expected in the variable. Likewise, Foreign Direct Investment (FDI) is a variable of concern because capital importation equally experienced a setback during the pandemic. The graph in Figure 2 indicated a drastic fall in export in 2020 while import, growth rate and FDI decreased as the result of the pandemic, although, the experience about capital flows differs from one country to another. Therefore, we cannot categorically say that structural break is expected. Though in African economies, the interest rate was nose-dived, the investible populace was looking for where to invest and safeguard their wealth, the main prompter of majority investment drive towards cryptocurrency.

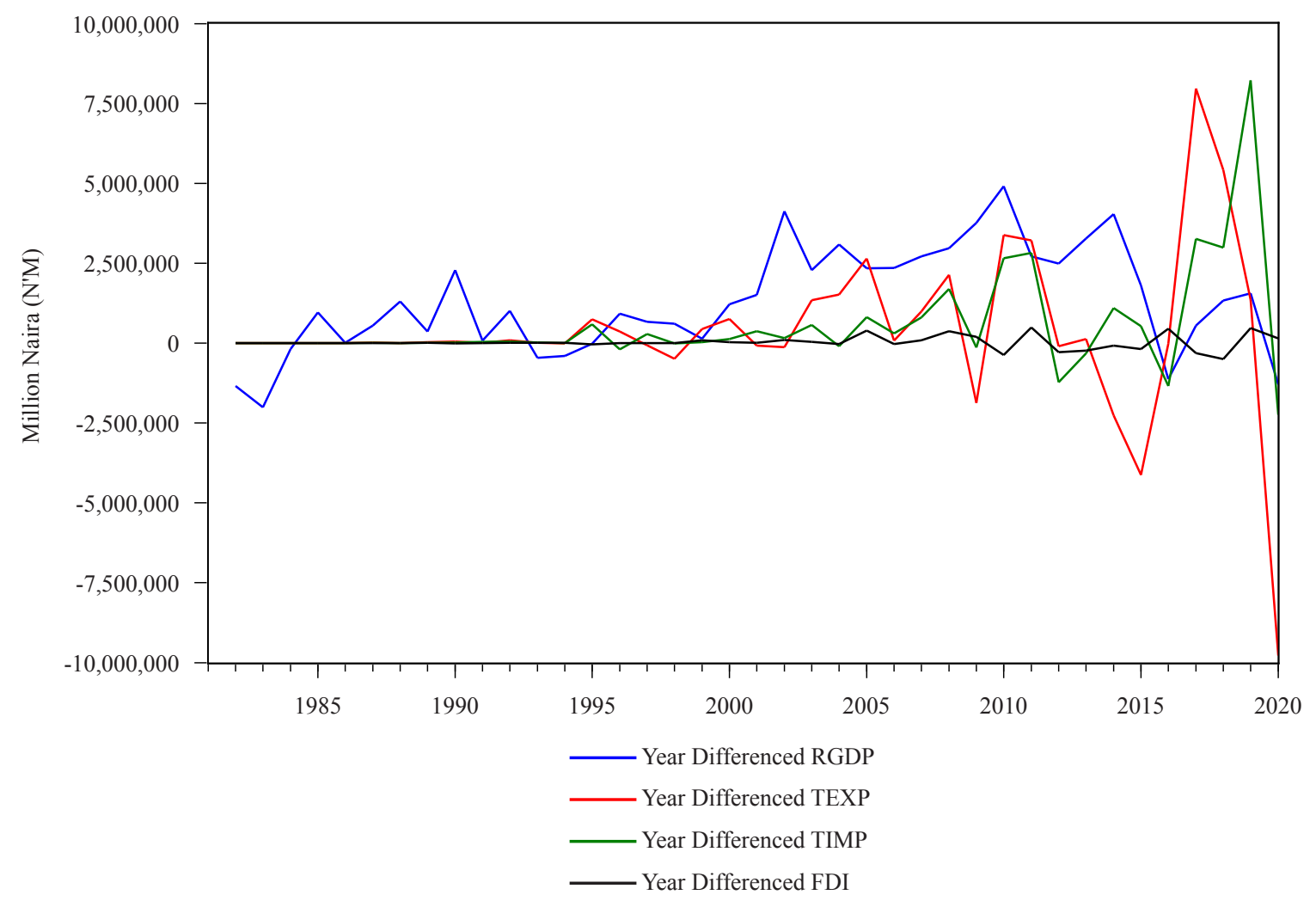

Figure 2. Line Graph of growth rate of GDP, export, import and foreign direct investment Source: Authors Computation 2021

The aforementioned practices indicated that multilateral trade systems pursued by WTO are limited in their capacity to address the present crisis imposed on international trading situations. Likewise, it has been revealed that WTO had little capacity to manage emergency trade activities with consultations with other trading partners. In addition, there was a lack of provision for a safety net for countries vulnerable to shocks in trade during the crisis. Lower-income and small countries with openness and high dependence on trade had to tolerate the burdens of export restrictions on essential goods. In this regard, the WTO guidelines permit countries to employ export restrictions under special 
conditions (Under article XI of the General Agreement on Tariffs and Trade). Nevertheless, this was not associated with provisions to lessen the uneven burden transferred to import-dependent countries (UNCTAD, 2020).

Presently, the pandemic has moved the market into online transactions in sectors of finance, telecommunication, retail, education, audio-visuals and health, thereby increasing online operations and procuring a shift to long-term online services. This strongly affected trade by increasing the supply of services via digital network (WTO, 2020). The policies of social distancing generated an overall strong effect on service trade and service sectors. Governments adopted several measures relating to mode of supply and service sectors during the crisis. Majority of which are trade-facilitating, i.e., measures to facilitate access to internet and mobile data to enhance online health and education services; measures to introduce flexibility for suppliers of transportation and enhance supply for cross-border transport of freight; measures to make available telecommunication facilities and regulations of bank requirements in providing credit to citizens (WTO, 2020).

With the second phase of the pandemic, the ongoing trade tension calls for alarm. There is need for confidence and cooperation in the global market for gradual stability. In addition, due to the collapsing demands by firms and the uncertainty in the severity of the virus, unnecessary policies of trade are to be avoided. The imposition of extra cost on consumers and firms through tariffs caused more burden on those affected by the crisis. Therefore, government ensured optimistic procedures in reducing the burden and enhanced confidence in the global market by evading imposition of new trade-restrictive measures or tariffs (OECD, 2020).

\section{Theoretical reviews}

Empirical research ascertained the theoretical forecast that trade in goods and services can be explained by changes in comparative advantage crosswise countries. But authors like Edwards (1993); Imbs and Wacziarg (2003) argued that development needs a minimum level for the benefits of diversification and export promotion to be actualized. The harmful consequence of high dependence on export of primary commodities was instituted on the assumption that export of primary products is influenced by secular decline in their terms of trade. It was also noted that the export of primary products may be categorized by low productivity and high price volatility (Singer, 1950; Prebisch, 1950; 1959). Likewise, it was argued that Dutch disease which represents the transmission of income from developing to developed countries brought about concentration in resource export and restrain possibilities for productive growth (Sachs \& Warner, 2001). In other words, export promotion and import substitution policies have been adopted by most government of developing countries with variable degrees of successes.

Export diversification not only entails increasing the variety of exported goods but also aided movement of goods of higher quality into new markets (Hausmann et al., 2007; Brenton \& Newfarmer, 2007). Consequently, higher technological intensity and more refined export baskets are likely to act as a catalyst for economic growth. Any economy that depends on export of raw materials will surely be trapped in a Dutch disease condition. In this case, Zeufack (2002) revealed that a shift from a traditional economy to a modern economy leads to a change in the structure of simple export product to complex export products. Furthermore, it was revealed that a progressive shift from resource-and-labourintensive to capital-and-technology-intensive exports occurred when there was a significant change in China's trade pattern and industrial structural adjustment (Caporale et al., 2015).

\subsection{Literature review}

International Monetary Fund (2011) examined the factors causing changes in trade patterns and their implication for global trade patterns in developed and Emerging Market Economies (EMEs). It was realized that the expansion of regional and global trade was driven by trade liberalization, vertical specialization and income convergence, especially the intra-industry trade. However, it was comprehended that the Asian supply chain was more dispersed compared to North America or Europe. Nevertheless, the greater dispersion of production in Asia rendered it more vulnerable to trade flow disruption. The emergence of global supply chain has helped EMEs in technological advancement through hightechnological export to advanced countries. As regards to this, China improved in their value-added chain in terms of high-technological exports. It was concluded that the improvement in a global chain can be linked to interconnectivity among countries in the world. Nicita and Tumurchudur-Klok (2011) investigated the decline in international trade, 
whether it was affected more by intensive margin (traditional trade flow) or extensive margin (new trade flow) in New York and Geneva. The result indicated that the 2008 and 2009 economic crises had severe implications on bilateral trade flow that did not exist before 2006. It was further found that new bilateral flows have lower probability of survival when it comes to a negative effect on trade volume and decrease in demand. Additionally, delay in the product cycle and greater exporters gaining grounds compared to new entrants is also one of the effects of the economic crisis. Furthermore, the results suggested that there are other important determinants in explaining the effect of the crisis on trade flows. Likewise, the volume of trade flow tells the magnitude of the consequence of the crisis, i.e., more trade flow could be less affected.

Caporale et al. (2015) investigated trade flow between China and its major partners in North America, Asia and Europe. Panel data based on both an economic indicator and gravity model, based on unobserved heterogeneity, Fixed Effect Vector Decomposition (FEVD) from the period between 1992 and 2012 was used. The result indicated a significant change in the structure of China's trade in connection to fast growth in foreign trade. The pattern of trade has moved from resource-and labor intensive to capital-and technology-intensive export. Also, comparative advantage has been developed in the capital-intensive sector vis-a-vis telecommunication, sound recording equipment and office machines. In addition, massive technological transfer via intermediate goods has enhanced China's manufactured export. Technological advancement has aided competitive and international industries to trade their export with the developed economies. The increase in trade machinery chunks and convergence in the composition of imports and exports show that intra-industry trade is of great importance in recent years. This has therefore fostered economic growth in China.

In Africa, Agarwal and Mulenga (2020) examined the impact of Covid-19 on international trade in African LDCs. The findings indicated the importance of African LDCS to sign a plurilateral agreement with existing economicallyadvanced trade partners to make sure that no new protectionist action is initiated against the LDCs in the period of crisis. Also, it was deduced that AfCFTA can provide opportunities for promoting resilience in regional trade relations as a result of cooperation between LDCs in Africa. In addition, the maintenance of food security in African LDCs is of great importance in bargaining for future trade agreements. Mveyange and Mold (2020) evaluated the impact of the Covid-19 predicament on regional trade in East African Community (EAC) using Kenya trade data up to May 2020. It was discovered that before the first quarter of 2020, there was an improvement in Kenya's export with moderation in imports resulting in a trade deficit. But during the Covid-19 crisis, domestic export performed extraordinarily but not all supply chain was interrupted by the crisis. In other words, the import of capital goods was a principal victim of the crisis, it declined for over 3 months during the crisis. In addition, Kenya's re-export and intra-regional trade were attributed to their role in intra-EAC trade, therefore, there is urgency for the implementation of the African Continental Free Trade Agreement (AfCFTA) to aid trade facilitation to mitigate the negative effect of the crisis.

In Nigeria, Bello and Gidigbi (2021) investigated the effect of trade on economic growth in Nigeria, particularly to determine if Covid-19 matters. They found out that the pandemic disrupted the global trade, which hit Nigeria due to the measures of lockdown of economic and social activities. It was envisaged that the occurrence of the pandemic pushed various economies into digital trade. Furthermore, there is need for a long-term trade-related technological advancement to aid trade processes and facilitation. Karimo et al. (2016) investigated the factors affecting Nigeria's trade with the global world. Time series data spanning from 1981-2012 were analyzed with error correction technique. The result showed that oil trade dominated total trade at about three times that of non-oil trade. Also, industrial output was prominent in explaining total trade adjustment to equilibrium and balance of trade. It was concluded that trade pattern in Nigeria does not conform to Hescher-Ohlim theory of factor endowment. Shuaib (2020) examined the pattern of international trade in Nigeria. The current status and situation of international trade were investigated when the new government re-introduced the policy of import substitution which was replaced by an export-oriented policy. Secondary data was used as evidence-based for discussion in the study. The paper discovered that the establishment of ministry for digital economy and the recent foreign trade policy contributed to GDP. After a critical review of current literature, it was concluded that there are numerous changes in the pattern of international trade among countries from boom to recession, and changing environment to trade policies. 


\subsection{The pattern of trade flow in developed and emerging countries in the pre-and post-era of Covid-19 crisis}

International trade in developed countries improved further to five-fold to about $\$ 15$ trillion in 2008 in the last 20 years. But for developing countries, export growth increased faster from about $\$ 800$ billion in 1990 to around $\$ 5$ trillion in 2008. Most increase in trade was coined to increase in volume of existing trade flows. Nevertheless, growth at the extensive margins which was due to export of new products or exports to new markets had been very low (Brenton \& Newfarmer, 2007; Amurgo-Pacheco \& Pierola, 2007). In exploring economic development, countries that were able to expand their export of new products performed better as regards economic growth (Hausmann et al., 2006). Nevertheless, it was believed that the export of new products anticipated future export potentials in a country. But a stronger repercussion for economic growth existed when shrinking demand had relatively negative effect on new export flows in developing countries (UNCTAD, 2011). In this case, the most affected goods in terms of merchandised trade in the period of the pandemic for the United States, China and the European Union were footwear, skin and leather and clothing and vehicles, which declined by about 20\% (International Trade Center, 2020).

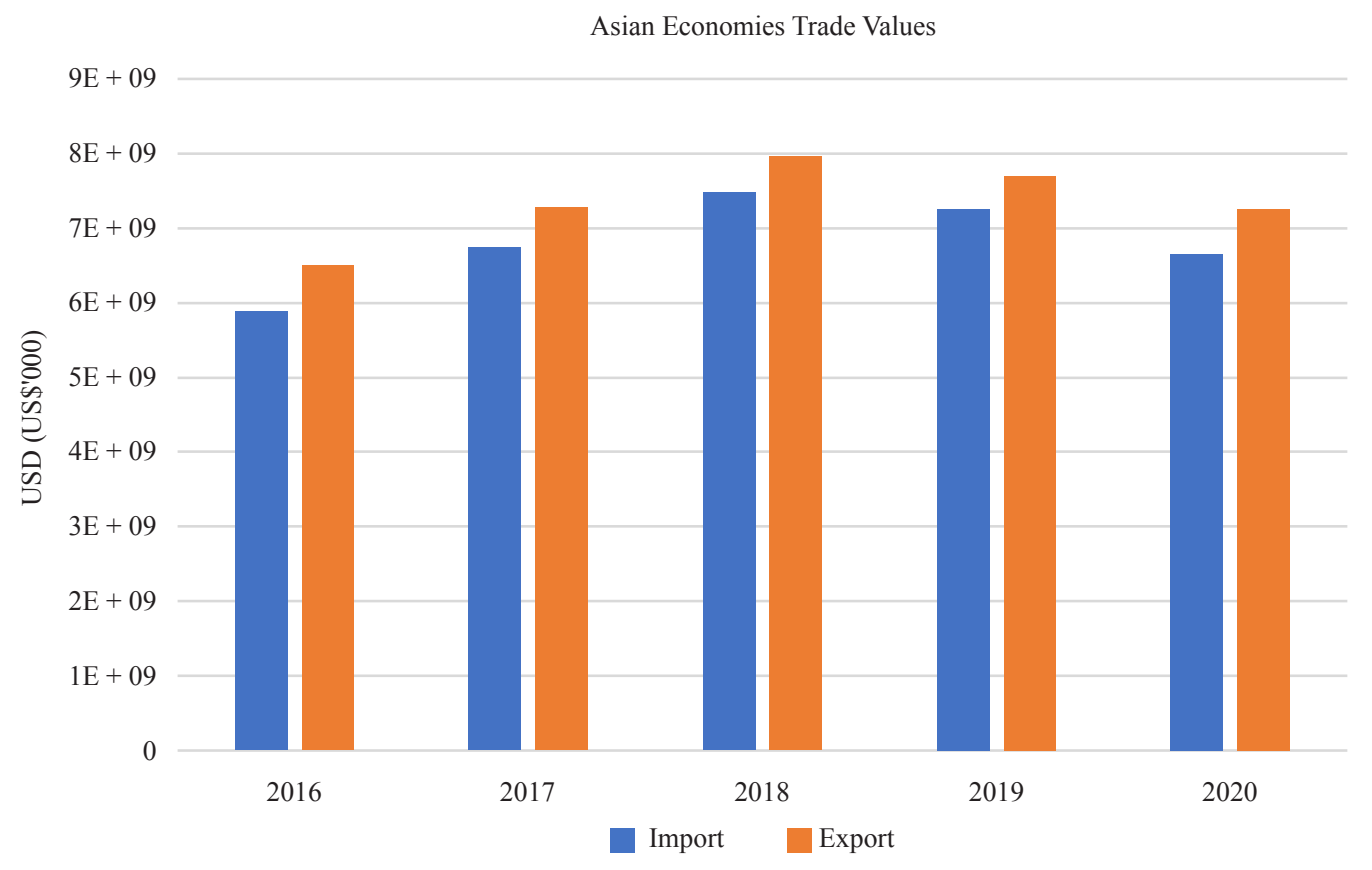

Figure 3. Asian Economies' Import and Export in Values (US\$'000)

Source: Authors Computation using data from ITC calculations based on UN COMTRADE and ITC statistics (2021)

The major trading partners accounted for about $64 \%$ of supply chain exports and about $63 \%$ of supply chain imports. According to ITC (2020), the global disruption of manufacturing inputs totalled \$126 billion while factory shutdown in European Union had the greatest effect on supply chain exports of other countries. The graph in Figure 3 above showed that the Asian economies experienced an increase in exports and imports in 2017, 2018 and 2019 but a drop in 2020 as a result of the pandemic. Similarly, there was a dip in trade flow in the developed economies trade as depicted in Figure 4. Subsequently, the EU which was the topmost importer of industrial inputs and exceedingly integrated into the global supply chain was the major market for Asia and Africa. It was predicted that African exporters as a result of shocks caused by factory closure in the United States, the EU and China may lose close to \$2.4 billion in global supply chain exports. Global trade increased progressively since World War II as development was accelerating over the past decades. Even in the phase of post-crisis dip, the level of gross export was three times that in the 1950s. Commodity trade accounted for a falling share of growth with the exclusion of commodity-price boom in the 1970s 
which was visible in 2004-2008. The growth of global trade can be ascribed to the following: improvements in regional trade; movements towards higher technology export near emerging market economies (EMEs); an increase in EMEs (IMF, 2011). The advancing roles of the global supply chain in overall trade can be attributed to the expansion of various tiers of trade. These were facilitated by communication cost, the technological-led decline in transportation and lower tariffs. On another hand, a vertical specialization that aids fragmentation of the production of certain goods into numerous stages in the most cost-effective location. This abetted the transformation of the products as goods cross several borders to be changed into final products which helped to increase trade interconnectivity. The sourcing of production phases from advanced countries has also abetted the shift in technology of export towards the latter (IMF, 2011).

Trade was confined to advanced economies in the early 1970s, especially Germany, Japan and the United States which altogether accounted for over a third of global trade. In 1990, global trade became more diversified to accommodate some EMEs, most especially from East Asia. But most surprisingly, China became the second-largest trading partners by 2010, surpassing Japan and Germany. The success of China was ascribed to openness to trade and rapid industrialization processes. Invariably in 2008, China's trade was 57\% of GDP which practically tripled the ratio of the US (IMF, 2011). Regional concentration was overtaken by global trade, which allowed exchange of goods and services with numerous countries around the world. Growth in intra-regional trade was predominantly strong in Europe and Asia, however, interregional trade was nearly unchanged at around 12\% of the world GDP between 1980 and 2009 (IMF, 2011). The improvements in global and regional trade patterns were aided by three (3) major factors which are (a) Increase in vertical specialization: This is linked to the process of fragmentation of production processes. Technological advancement in transportation and communication supported the cut in the cost of oversight and management and this made different stages of production visible across countries. On another hand, low tariffs and transportation costs also facilitated movement of intermediate goods through specialization in particular stages from one country to another via the global supply chain. Therefore, growth in vertical specialisation was fast-tracked by increment at about more than 20\% in 2005. (b) Convergence in the level of income: The volume of trade increases GDP when counties in the composition of their factor endowment converge in their level of income (Hummels \& Levinsohn, 1995). (c) In terms of inter-industry trade, firms produce different goods at an increasing-return-to scale.

Developed Market Economies Trade

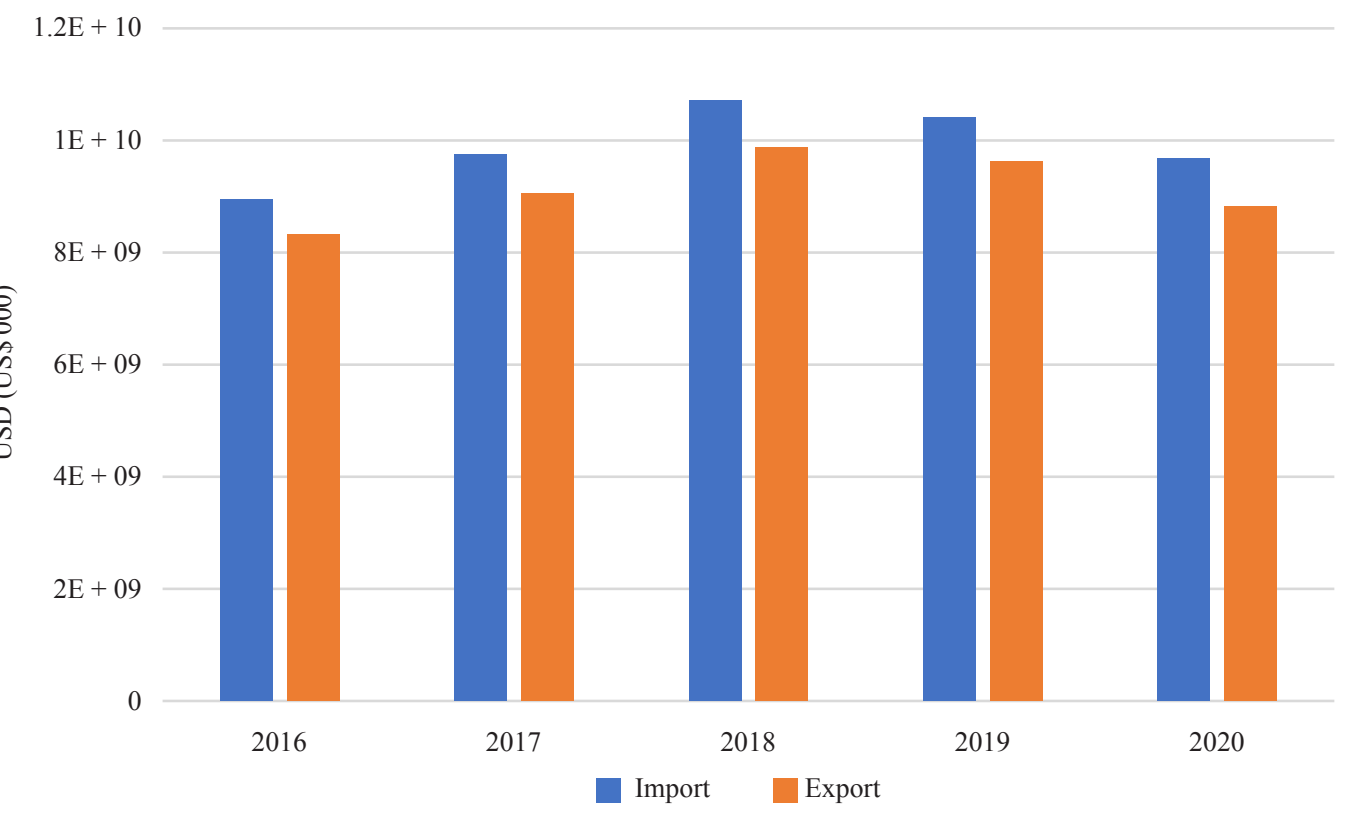

Figure 4. Developed Market Economies' Import and Export in Values (US\$'000)

Source: Authors Computation using data from ITC calculations based on UN COMTRADE and ITC statistics (2021) 
Globally, the pandemic ignited the importance of services such as telecommunication, online supply and computer services. It also broadened the infrastructural role of financial, logistic, distribution and transport services in facilitating trade. The online services were increasing the resilience in coping with the pandemic by facilitating tele-education and telework. This aided digital disparities and policy trials concerning online service supply. The creation of this situation was and still conducive for trade in services with diverse modes of supply which is key to recovery in the current crisis. However, in other to curtail the spread of the virus, online sales particularly by the retailers and wholesalers were the most convenient and safe in a bid to ensure social distancing. This expanded online businesses in the area of delivery and pickup services. The pandemic accelerated sales of consumer goods to online network as consumers were daily delving into the system and retailer and wholesalers were expanding their online operations. However, various challenges were faced by online retailers in the aspect of supply chain and inventory shortage which caused several setbacks and delays in delivery and cross border distribution. It was also noted that distributional sectors differ across economies due to the level of e-commerce development and lockdown policies (World Economic Forum, 2020).

\subsection{The pattern of trade flows in Africa during the pre-and post-Covid-19 crisis era}

The export structure of most developing countries had virtually remained the same and majorly concentrated on primary products. For example, the export of sub-Sahara African (SSA) countries mainly consist of metals, fuels and ores. However, there were anxieties about the increasing trend of deindustrialization in some developing countries, whereby the share of manufacturing value-added in GDP was decreasing and negatively impacting structural transformation (Söderbom, 2017). The peculiarity about Africa countries as presented in Figure 5 showed that export was drastically low compared to import in 2020. Consequently, the data for import and export in 2018 and 2019 was a little lower in comparison to 2019 when the pandemic struck. Even though it peaked up in 2018 compared to 2016 and 2017 respectively. In other words, developing countries tend to import more manufactured goods to enhance productivity and as a means of technological transfer. Trade possesses the ability to contribute to production and export diversification but the rate at which the potential benefit is realized differ from one country to another. This can be ascribed to country-specific policies and initial conditions which affected trade and production performance.

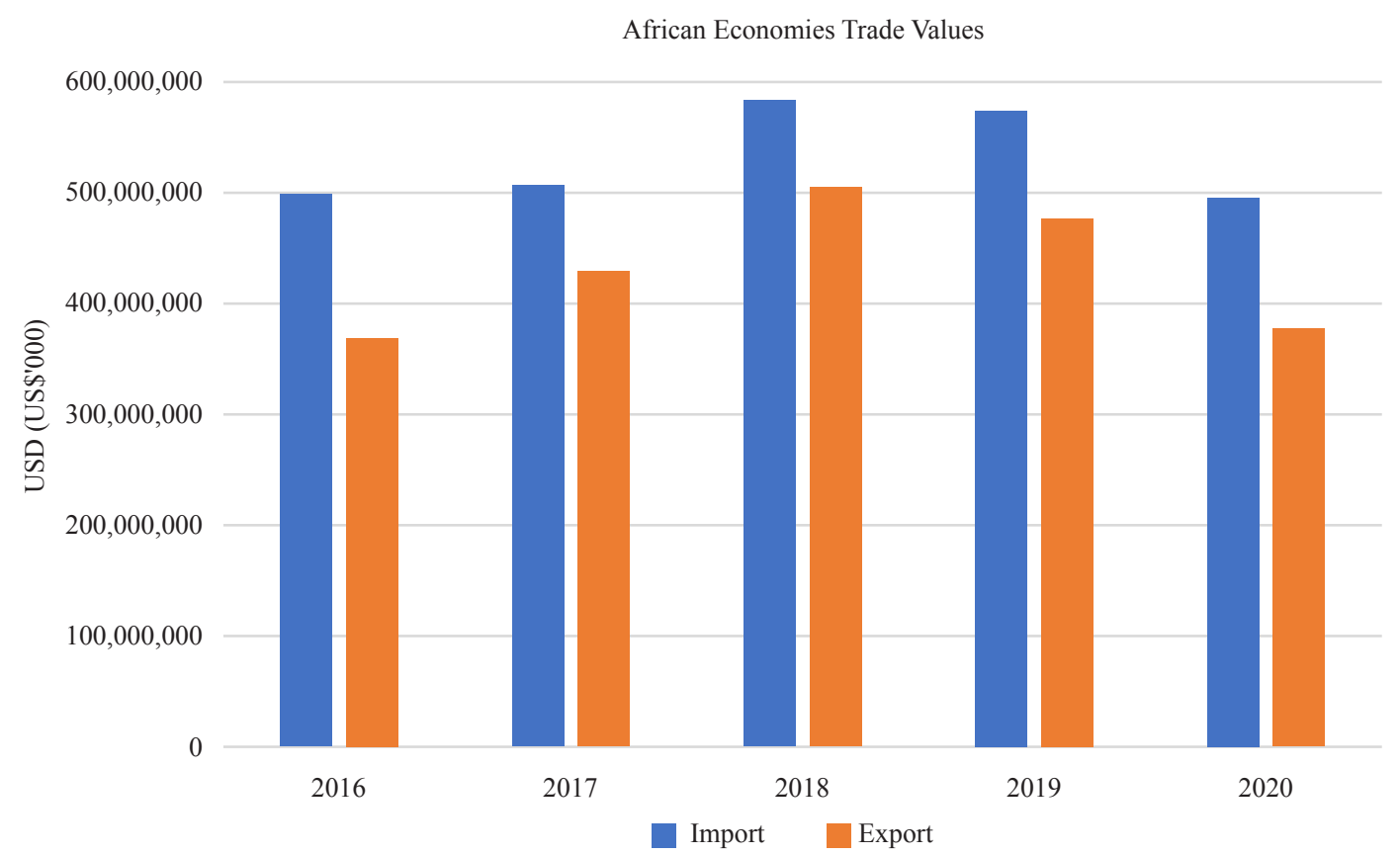

Figure 5. African Economies' Import and Export in Values (US\$'000)

Source: Authors Computation using data from ITC calculations based on UN COMTRADE and ITC statistics (2021) 
The global crisis had instigated market failure in most countries and this posed threats to international trade. This is likely to destroy the gains already made in trade over the past decades. This impact is expected to be severe compared to that in the 2008/2009 GFC as it affected aggregated supply and demand resulting in interruptions in the global value chain, most especially in trade of goods and services. In the era of the crisis, the restriction of movement and measures of social distancing led to the collapse of production activities, this generated a severe implication for consumers and producers in numerous countries as various sectors were shut down. In this case, the most affected countries were the least developing countries (LDCs) that were depended on trade of goods and services.

The major exports by Africa countries are commodities like cocoa, coffee, minerals and oil and these products face major threats in the disruption of supply chain due to low demand for export in the global markets. The general slowdown in growth across the world caused lower export earnings for major African exporters. Consequently, where most LDCs relied on inputs from developed countries, Africa's import was over 50\%, constituting transport equipment and industrial machinery from China, Europe and India at 16\%, 35\% and 14\% respectively. But with the incidence of the Covid-19 crisis, there was an abrupt distortion in supply chains with China and Europe which led to the unavailability of intermediate and final goods (Agarwal \& Mulenga, 2020). Africa countries have been undergoing growth in trade since the last few years but there was a contingent need for international trade agreements to support their growing export sectors. The ongoing crisis was an opportunity for African continents to align with the African Continental Free Trade Area (AfCFTA) aims and objectives. This would help to make concrete efforts in harmonizing trade-related issues, reduce tariff and non-tariff barriers and control customs to foster international trade.

The pandemic also hit the LDCs who were dependent on international trade as a driver of economic growth. The low level of diversification and small domestic markets made them more vulnerable to external shocks. Trade accounted for over 53\% of their GDP in 2018 in which 33 out of the 47 LDCs located in Africa were severely affected due to trade-restrictive policies pronounced by numerous countries in the world (Agarwal \& Mulenga, 2020). In addition, to strengthen the participation of industries situated in the LDCs region value chain, it was imperative to reduce essential goods and food supply vulnerability to make African economies resilient to future endemics and crisis. In addition, it is important to deliberate on the excessive cost and sustained trade network while venturing into future negotiations on regional or bilateral trade agreements in Africa.

General restriction and export bans on virus-related products covered 73\% of the world trade in May 2020. In a bid for adjustment, about 93 countries employed temporary export measures on medical products and food to ensure adequate access to essential goods (ITC, 2020). But export bans and restrictions differed from one region to another. Some African countries are attributed to the fact that they do not manufacture products related to Covid-19, so they restricted export of such goods. The products prone to export restrictions were masks with 48 measures and mask filters and 55 textile masks. Meanwhile, the World Trade was affected at $76 \%$ and $90 \%$ in the two products respectively. The share of imports of Covid-19 related goods was highest in Africa at $74 \%$ due to restrictions that varied by regions. In comparison with other regions, it was $67 \%$ in Asia-Pacific and $60 \%$ in the American regions. In order to facilitate access to food and essential material in the era of Covid-19, about 105 countries employed temporal measures on the importation of goods. While about $46 \%$ of developing countries reduced tariffs on medical products, $18 \%$ applied the policy in least developed countries but nearly three-quarters of developed countries complied (ITC, 2020).

Taking Nigeria as a case study of ECOWAS countries, the high demand for imported goods compared to locallymade goods are the main issue. As indicated in Figure 6, exports increased from 2016 to 2017, but peaked up in 2018 and 2019 due to policy implementations to regulate trade in Nigeria. But in 2020, due to the pandemic, export was very low. Import on the other hand, was high in 2016 but low in 2017 due to the introduction of Nigerian Autonomous Foreign Exchange Rate fixing (NAFEX). It then rose in 2018 and increased in 2019. But as a result of the pandemic, it rose drastically in 2020. The opportunities to tap into high scale production and export of rice is still not achievable as local rice production is still at a low scale for exportation. Contrary to this, some government officials still prefer to import rice from Brazil, India and Thailand (Depetris-Chauvin \& Porto, 2014). On another hand, the similarities in the major exports of ECOWAS countries like cocoa, bovine animals, cotton, coffee, sesame and tobacco. While the exports of natural products are gold, ore, uranium, crude oil etc (Osabuohien et al., 2017). The inability of ECOWAS countries to initiative value addition in the processing of their major export within the countries result into similarities of export (Efobi \& Osabuohien, 2015). This would have been an avenue to increase competitively their products and trade diversity in the global market. 
$600,000,000$

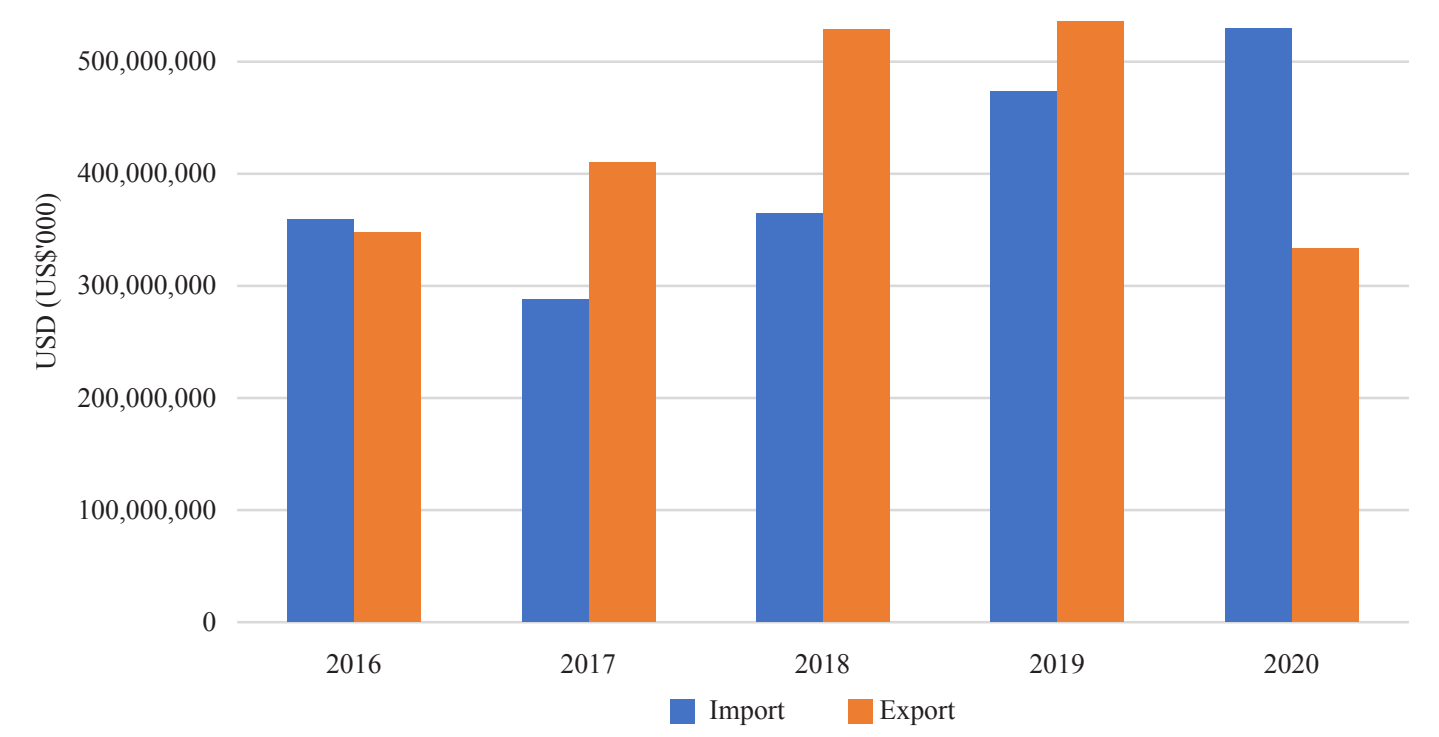

Figure 6. Nigeria Import and Export in Values (US\$'000)

Source: Authors Computation using data from ITC calculations based on UN COMTRADE and ITC statistics (2021)

The total trade with respect to industrial exports is $\$ 59,810$ million (ITC, 2020). But in the annual projections for 2020, the international supply chain was disrupted by Covid-19. The most affected sectors were: skin, leather and product thereof; wood products; metals; natural latex and rubber; miscellaneous manufactured products and other subsectors; supply chain export loss amounting to $\$ 59,810$. The projected expected export loss of industrial inputs to G3 countries added up to about \$36 million in which loss to China, EU and US amounted to \$10 million; \$25 million and $\$ 1$ million respectively. On the other hand, the projected supply chain imports loss by most affected sectors include: boats and ports, plastics and rubber; skin, leather products thereof; natural latex and rubber; wood products and other substances amounted to $\$ 284$ million. Subsequently, the projected expected loss of imports of industrial output to G3 countries totalled \$29 million whereby a loss of \$18 million, \$8 million and \$2 million to China, EU and the US respectively (ITC Market Analysis Tools for Trade Statistics, 2019).

Due to import-dependent-type of country, the high concentration of imports of medical products in Nigeria made her vulnerable to shortage in supplies from the top producing countries. Out of the 46 items for screening, surveillance, clinical management and triage, 17 products were prioritized as key items by WTO Covid-19 Disease Commodity Package (DCP) to deal with the current predicament. The major items were essential items for treatment and diagnosis such as oxygen concentrator, enzymes, personal protection equipment and liquid soaps. Nevertheless, an average of $80 \%$ of Nigeria's import made up the top three exporters. The concentration of imports was high for key products such as gloves, heavy-duty apron, protective goggles, nitrile and sterile gloves and medical gloves. Also, the major imports of medical masks, which were majorly $90 \%$ of Nigeria's import were subjected to export restriction leading to an increase in price at about $40 \%$. The same restrictions was also placed on drains and probes, catheters and bougies, resulting in a hike in prices of about 20\% (World Bank Group, 2020).

In comparison with global average, Nigeria possessed higher tariff for selected products but moderate tariff on medical products. Import restrictions were higher for hygiene and personal protective equipment while average tariff for Covid-19 medical products were at $8 \%$. This affected the Nigerian government and their inability to respond to the crisis at an early stage. Consequently, on non-tariff measure, import license was imposed by Nigeria for medicine, ventilators and protective garments. Meanwhile, most personal protective equipment and Covid-19 products were subjected to pre-shipment inspection but imports of disinfectant and tissue paper were banned. But for safe and effective deal with current endemic, options like eliminating unnecessary import restriction, diversifying imports, streaming of non-tariff 
measures on Covid-19 medical goods and reducing taxes such as VAT was acted upon (Espita et al., 2020).

The World Bank survey on Covid-19 revealed that trade was the most affected sector. This was ascribed to the fact that trade sector accounted for 33.0\% of Nigeria's GDP in 2018 which declines to $16 \%$ in 2019. The GDP in 2020 was bound to further decline as the growth rate of trade was at $0.27 \%$ in the first quarter of 2020 (AITCR \& ITRC, 2020). This result indicated a decline of about 5.09\% in comparison with the first quarter of 2019. Additionally, series of total trade also decreased by $17 \%$, quarter by a quarter from US\$434.29 billion to US\$28.25 billion subsequently. More importantly, imports dropped by $19.7 \%$ at a decreased rate from US $\$ 17.23$ billion to US\$13.83 billion in the first quarter of 2020 . On another hand, exports decreased by $14.9 \%$ from US\$15.74 billion in the fourth quarter of 2019 to US\$13.39 billion in the first quarter of 2020 respectively. These fluctuating trade figures in combination with the global drop in the price of crude oil to as low as \$11.269 explained the gloomy trade system in Nigeria (AITCR \& ITRC, 2020).

The declining trend in the Nigerian trade balance as of September 2019 was N2.8 trillion in comparison to N5.4 trillion in 2018. The trade data for the fourth quarter of 2019 indicated a trade deficit and a further fall of N2.2 trillion. This contraction was ascribed to the negative effect of Nigeria's border closure on non-oil exports and drop in the price of crude oil export which plunged $43.9 \%$ in the fourth quarter of 2019. Furthermore, Nigeria's trade balance crept into a trade deficit of $\$ 1.6$ billion (N579 billion) in 2019 which was the first since the third quarter of 2016. These results implied that imports exceeded export in the quarters. However, the incidence of the Covid-19 pandemic led to low demand for crude oil, crude oil export was expected to fall further in 2020. Also, deficit in trade balance was expected as experienced in 2016 with enormous implications on external reserves, export earnings and government revenue (Nigerian Economic Summit Group, 2020).

In order to achieve economic resilience, borders were supposed to be opened despite diversifying destinations and origin of the market. Most of the emergency measures employed in the occurrence of the Covid-19 pandemic was classified as non-tariff measures. These addressed policy measures that influenced the flow of trade in goods and protection of human, productive safety, environmental sustainability and health. The closure of land borders and ongoing security issues before the incidence of Covid-19 was one of the impediments to growth in Nigeria. The border closure was authorized in August 2019 in a bid to address security concerns, protect domestic production and reduce smuggling. These actions caused contraction in growth in the fourth quarter of 2019, indicating the drastic slowdown in growth of trade in Africa (World Bank Group, 2020). If these policies were implemented properly, they would procure for each country social, environmental and economic gains. In addition, non-tariff policies addressed at least nine of the Sustainable Development Goals to foster economic development (United Nations, Economic and Social Commission for Asia and the Pacific (ESCAP) and UNCTAD, 2019).

\section{Changing pattern of international trade}

In 2018, Africa accounted for $2.6 \%$ of global trade in comparison with $2.4 \%$ in 2017 , but intra-African trade improved by about $16 \%$ in 2018 . This was attributed to the dominance of primary commodities and extraction of natural resources. This pattern continued to hinder Africa's participation in global trading system which was prevalent in manufactured and industrial production with an upsurge in technology. This heightened trade tension in 2018 as a result of trade war between the United States and its major partners which accounted for about $58.9 \%$ of the US trade deficit in 2018 (African Trade Report, 2019). Concerning the traditional system of trade and boundaries between jurisdiction and regulatory infrastructure at national, regional and global levels, it facilitated a multinational value chain and instigating new tradeable goods and services. Growth in the intensity of merchandise trade after a slower growth of $3 \%$ in 2018 was anticipated to decrease to $2.6 \%$ in 2019 (African Trade Report, 2019). Advances in global trade have been coined to increase trade interconnectivity and this has noteworthy implications on trade patterns especially relative price changes (Riad et al., 2012). Then, as trade liberalization contributed to reduce trade barriers in the early 1950s, digitization of trade in the era before and after Covid-19 will be of great advantages.

There were various changes in the area of trade, taxation, industrial policy, immigration, and intellectual property when the era of digitizing the economy was imbibed. Over 30 years, technological improvement in information and communication technology (ICT) had positively changed the forms of trade, communication and socialization. Therein, trade pattern was changing as a result of digitalization and most especially across borders before, during-and-postCovid-19 era. The availability of high technology facilities aided the expansion of global trade as a result of increasing 
non-commodity exports. This can be attributed to three (3) paradigm shifts: continuous changes in technology; increasing emerging market economies (EMEs) and upsurge in global supply chain.

During-and-the-post era of Covid-19, digital trade served as the main tool to boost intra-African trade. Also, technology served as a major factor in reducing trade costs in production through international networks (Amador \& Cabral, 2016; WTO, 2018). Numerous digital firms used ICT in place of the usual traditional pattern to confront challenges of trade (UNCTAD, 2019). In Africa, the proportion of the population using the internet increased from $16 \%$ in 2013 to $18 \%$ in 2016 and then rose to $25 \%$ in 2018 (UNCTAD, 2016; World Bank, 2019). The ongoing digital transformation has led to the integration of African countries with the world which led to overall economic development. It has increased trade, access to market and investment through effective delivery systems and regulatory payment through organizational processes and automation of existing businesses.

\subsection{The era of digital economy}

The global economy had shifted to digital era in almost every sector. This system has changed the pattern of disseminating information in the area of learning, communication, socialization in both the public and private sector including the trade of goods and services. The digital era penetrated all facets of trade, from agriculture to production, manufacturing and services. Digital trade had been on the increase recently and predominantly in the era of the Covid-19 pandemic. It represented physical trade in goods in some particular sectors like gaming and books. Digital aggregators such as Apple, Amazon, Spotify, YouTube, Netflix among others had recently intensified rapid economic growth and diversified into data and income monetization (Nurse, 2021). Due to the adoption of digital technologies, global trade growth was $2 \%$ higher per annum while trade growth in developing countries was envisaged to increase by $2.5 \%$ between now and 2030 (WTO, 2021). Accordingly, service export also had a bigger percentage of global trade, adding up more than a quarter of total trade by 2030. In addition, there will also increase in share of service imports of manufacturing output (Bekkers et al., 2021). On the part of transaction cost, it has been ascertained that trade costs online are lesser compared to offline trade (Lendle et al., 2016).

The significant inspiration about the digital economy is its evolving speed in the collation of information. It enables individuals to communicate and share information through the internet and various digital technologies across the globe. These have enhanced businesses and social activities on different platforms. Consequently, there has been a substantial increase in global data flow to 45,000 GB per second in 2017 which was projected to reach 150,700 GB in 2020 (Shuaib, 2020). The reports from WTO (2020) on the impact of Covid-19 divulged greater attention to online businesses in the area of telecommunication, health, education, wholesale and retail thereby speeding up online operations toward gearing online services. In the post-Covid-19 era, an upsurge in the supply of digital network is expected to meet up increasing demand for digital system, in which the volume of global trade increased drastically as a share of digital economy. The global digital economy was about USD11.5 trillion in 2016, and accounted for $15.5 \%$ of the world's overall GDP (Shuaib, 2020).

There is a rapid development in digital technology as the world is transforming fast to meet up the 2030 Sustainable Development Goals (SDGs). Reduction in costs of trade would empower trade flow in developing countries when digitalization is prominent. Therein, a reduction in the cost of trade as a result of regulatory policies and technological diffusion will raise developing countries' share of about 57\% in global trade by 2030 (WTO, 2018). In the simulation carried out on the intensive use of communication services and information technologies, it was revealed that due to falling trade costs, changes in technology would boost trade growth (Bekkers et al., 2021). Therefore, countries tend to intensify the exchange of goods and services when the importers and exporters adopt high internet facilities (Osnago \& Tan, 2016).

Presently, the participation in the digital economy by developing countries is on the increase but poor data availability is a major issue. Nevertheless, developing countries (Nigeria) are still far away as they contribute the lowest share to overall growth. Therefore, there is need for investment in digital economy to meet up with the viable benefits (The World Bank Group: Nigeria, 2019). Also, the level of digitalization of societies and the economy is procuring new means for undertaking challenges attributed to global development. Digital platforms have become a major resource in economic processes to capture value creation. But as the digital economy emerged in developing countries, there are limited signs of its impact on value creation. This created potentials for upgrading and distribution of the value chain. 


\subsection{Digital pattern of trade in Nigeria}

As survival strategies during the Covid-19 crisis, countries across the world created trade relationships for sustainability. Digital trade over the internet changed the pattern of international trade across the world. During the incidence of Covid-19, the smallest informal trade (demand and supply of goods and services) was transacted online through various platforms: text messages, e-commerce stores, and emails. Most formal trade like documentation, logistics, and financing was implemented more through the internet compared with the era before the lockdown. In order words, the Internet was used to conduct trade whether an online purchase, financial arrangement, or email. Developed countries with high technology had gone viral while developing countries are trying to meet up with their limited access and internet facilities. With respect to this, the Nigerian government in the third quarter of 2019 formed the ministry of communication and digital economy to increase its digital activities in order to generate employment and increase income through trade (Shuaib, 2020).

The volume of global trade increased drastically as most countries in the world were increasing and digitizing their activities. Subsequently, as developed countries replaced import substitution policies with export-oriented policies, policymakers in developing countries also introduced more open trade policies to leverage trade activities for sustainable development. Nigeria actively responded to the changing pattern of business across the globe by formulating policies that adhered to global trade policies. Amid the rising inflation, fluctuating exchange rate and unstable global oil price, government introduced various trade policies to improve the performance and participation in global trade. The government also embarked in the digitalization of the economy as one of the channels through which trade can be raised to a global standard (Shuaib, 2020). This was following the Nigerian economic recovery in 2017 in expanding growth and investment from 5\% in 2017 to $8.4 \%$ in 2020 (Leidong, 2019).

The incidence of Covid-19 established the importance of digitalization and telecommunication in daily activities. Digital innovations are the greatest invention in transforming the global economy. It is vital in boosting global trade flow in terms of information, cost, production and introduction of new products and markets, import and export from developed countries to developing countries, and vice versa. Consequently, digital technologies could be a threat and disadvantageous on the part of developing countries that lack the environment to compete with advanced digitalized environment. However, the ICT industries experienced tremendous growth during-and post-Covid-19 eras in Nigeria.

The projection by the government was that by 2025 , Nigeria will experience a digital economy and engage more than $15 \%$ of her labor force. But the major problem is Nigeria's comparison to the developed world lags in terms of internet facilities. An approximation of about $40 \%$ of person made use of the Internet in 2019 , while about $60 \%$ was visible in the rest of the world. Nigeria is fast growing but has not yet reached the critical Internet connection of about $20 \%$ required for effective investment in ICT infrastructure. The infrastructural facilities, cost, and access to digital development are still a hindrance to sustainable digitalization (Trade in the Digital Economy, 2020).

\section{Conclusion}

The global economies witnessed an unanticipated disruption and global economic shock transmission basically through trade. Trade has been pinpointed in snowballing the effect of the Covid-19 pandemic into a global effect. If trade could be a transmitter of negative effect, then, it must be very instrumental in transmitting recovery growth. The findings from the data and charts infer that the Covid-19 crisis caused a decrease in global trade during and post-pandemic era which was also dominant in African countries (Nigeria). The pandemic aggravated the pattern of trade in terms of import and export as Nigeria was already in a fragile economic situation. Government and all concerned stakeholders resulted in a reversal plan through trade, by gradually opening up their economies and ensuring entrenchment of stakeholder's trust in the system. The pandemic shifted the global attention to digital economy as the best choice even though it has been in existence and embedded numerous advantages which creates a wide gap between developed countries with sophisticated technologies and developing countries with limited access. Nigeria, with a rising market for mobile trade due to her large population was open to opportunities for achieving the objectives of a global economy. While undergoing growth in trade for the last few years, there is a contingent need for international trade agreements to support its growing export sector. In addition, Nigerian government should invest more in digital economy to facilitate effective connectivity and easy access with policies to support online businesses and transactions as this method is more 
effective in the post-Covid-19 era. Also, internet facilities should be made available and subsidized to ease connectivity and access to sustainable digital economy in future.

\section{Conflict of interest}

The authors declare that there is no personal or organizational conflict of interest with this work.

\section{References}

Africa International Trade and Commerce Research \& International Trade and Research Centre. (2020). New normal: Nigeria trade policy in a post-covid-19 pandemic.

African Trade Report. (2019). African trade in a digital World. Cairo. https://s3-eu-west-1.amazonaws.com/demo2. opus.ee/afrexim/African-Trade-Report_2019.pdf

Agarwal, P., \& Mulenga, M. C. (2020). Impact of Covid-19 on international trade: Lessons for African LDCs. Policy Brief, 1-19. http://dx.doi.org/10.2139/ssrn.3693901

Amardor, J., \& Cabral, S. (2016). Global value chains: A survey of drivers and measures. Journal of Economic Survey, $30(2), 278-301$.

Amurgo-Pacheco, A., \& Pierola, D. (2007). Patterns of export diversification in developing countries: Intensive and extensive margins. Graduate Institute of International Studies. Geneva. https://www.researchgate.net/ publication/5080876

Bekkers, E., Koopman, R., Sabbadini, G., \& Teh, R. (2021). The impact of digital technologies on developing countries' trade. In M. Smeets (Ed.), Adapting to the digital trade era: Challenges and opportunities (pp. 36-51). Geneva CH: WTO Academic Work Experience Teaching Experience.

Bello, K. M., \& Gidigbi, M. O. (2021). The effect of trade on economic growth in Nigeria: Does Covid-19 matters. African Journal of Economic Review, 9(3), 21-33.

Brenton, P., \& Newfarmer, R. (2007). Watching more than the discovery channel: Export cycles and diversification in development. World Bank Policy Research Working Paper No. 4302. World Bank, Washington D.C.

Caporale, G. M., Sova, A., \& Sova, R. (2015). Trade flows and trade specialisation: The case of China. China Economic Review, 34, 261-273.

Depetris-Chauvin, N., \& Porto, G. (2014). Agricultural supply chains and farmer's constraints: Welfare impacts in ECOWAS countries. Working Papers 2014-20, CEPII Research Centre.

Edwards, S. (1993). Openness, trade liberalization, and growth in developing countries. Journal of Economic Literature, 31(3), 1358-1393.

Efobi, U., \& Osabuohien, E. (2015). Manufacturing export, infrastructure and institutions in Africa: Reflections from ECOWAS. In D. Seck (Ed.), Accelerated economic growth in West Africa (pp. 157-179). Geneva: Springer International Publishing.

Espita, A., Lee, W., Rocha, N., \& Ruta, M. (2020). Nigeria: COVID-19 trade snapshot. World Bank Group Trade and COVID-19 Guidance Note.

Hausmann, R., Hwang, J., \& Rodrik, D. (2006, March). What you export matters. Harvard University. CID Working Paper No. 123. Faculty Working Paper. https://www.hks.harvard.edu/centers/cid/publications/faculty-workingpapers/what-you-export-matters

Hausmann, R., Hwang, J., \& Rodrik, D. (2007). What you export matters. Journal of Economic Growth, 12(1), 1-25.

Hummels, D., \& Levinsohn, J. (1995). Monopolistic competition and international trade: Reconsidering the evidence. Quarterly Journal of Economics, 110, 798-836.

Imbs, J., \& Wacziarg, R. (2003). Stages of diversification. American Economic Review, 93(1), 63-86.

IMF. (2011). Changing patterns of global trade. Prepared by the Strategy, Policy, and Review Department, International Monetary Fund. https://www.imf.org/external/pubs/ft/dp/2012/dp1201.pdf

International Trade Centre. (2020, June). SME Competitiveness Outlook 2020: COVID-19: The great lockdown and its impact on small business. ITC Geneva. https://www.intracen.org/uploadedFiles/intracenorg/Content/Publications/ ITC_SMECO-2020ExSummary_EN_web.pdf

Karimo, T. M., Krokeyi, W. S., \& Ekainsai, S. Z. (2016). Factors Influencing Nigeria's Trade. Developing Country Studies, 6(1), 36-42. https://www.iiste.org/Journals/index.php/DCS/article/view/28053 
Leidong, T. A. (2019, October 28). Nigeria's border closure has implications for Africa's economic integration. https:// www.polity.org.za/article/nigerias-border-closure-has-implications-for-africas-economic-integration-2019-10-28

Lendle, A., Olarreaga, M., Schropp, S., \& Vezina, P. L. (2016). There goes gravity: e-Bay and the death of distance. The Economic Journal, 126(591), 406-441.

Mveyange, A., \& Mold, A. (2020, July 13). The impact of the COVID-19 crisis on trade: Recent evidence from east Africa. Policy Brief. https://www.trademarkea.com/the-impact-of-the-covid-19-crisis-on-trade-recent-evidencefrom-east-africa/

Nicita, A., \& Tumurchudur-Klok, B. (2011, January). New and traditional trade flows and the economic crisis. United Nations Conference on Trade and Development. Policy Issues in International Trade and Commodities Study Series No. 49. https://www.researchgate.net/publication/237500401

Nigerian Economic Summit Group. (2020, May 11). Macroeconomic outlook updates: COVID-19, global oil price and the Nigerian economy. Nigerian Economic Summit Group. https:/www.proshareng.com/admin/upload/ report/13476-May\%202020\%20Macroeconomic\%20Outlook-proshare.pdf

Nurse, K. (2021, April). The digital creative economy and trade: strategic options for developing countries in WTO: Adapting to the digital trade era: Challenges and opportunities. Geneva. https://www.wto.org/english/res_e/ booksp_e/16_adtera_chapter_12_e.pdf

OECD. (2020, May 7). COVID-19 and Africa: Socio-economic implications and policy responses. https://www. oecd.org/coronavirus/policy-responses/covid-19-and-africa-socio-economic-implications-and-policy-responses$96 \mathrm{e} 1 \mathrm{~b} 282 /$

OECD. (2020, June 12). Covid-19 and international trade: Issues and actions. Speeding up Africa's response to covid-19: What can technology, manufacturing and trade do? https:/www.oecd.org/coronavirus/policy-responses/ covid-19-and-international-trade-issues-and-actions-494da2fa/

Osabuohien, E., Efobi, U., Odebiyi, J., \& Fayomi, A. (2017). Financial development, trade costs and bilateral trade flow: Connecting the nexus in ECOWAS. In D. Seck (Ed.), Investment and competitiveness in Africa (pp. 153-176). Geneva: Springer International Publishing. https://doi.org/10.1007/978-3-319-44787-2

Osnago, A., \& Tan, S. W. (2016). Disaggregating the impact of the internet on international trade. Policy Research Working Paper 7785, World Bank Group.

Prebisch, R. (1950). The economic development of Latin America and its principal problems. Economic Bulletin of Latin America, 7, 1-12.

Prebisch, R. (1959). Commercial policy in under-developed countries. American Economic Review Paper Proceedings, 492, 251-273.

Riad, N., Errico, L., Henn, C., Saborowski, C., Saito, M., \& Turunen, J. (2012). Changing patterns of global trade. Strategy, Policy, and Review Department, International Monetary Fund, Washington, D.C.

Sachs, J. D., \& Warner, A. M. (2001). Natural resources and economic development: the curse of natural resources. European Economic Review, 45, 827-838.

Shauib, K. M. (2020). The changing pattern of international trade: Import substitution policy and digital economy in Nigeria: A review. International Journal of Economics and Business Management, 6(4), 13-25.

Singer, H. W. (1950). The distribution of gains between investing and borrowing countries. American Economic Review, $40(1), 473-485$.

Söderbom, M. (2017, January). Learning to compete: evidence on exporting and firm-level performance. Journal of African Economies, 26(1). https://www.wider.unu.edu/publication/learning-compete-0

The World Bank Group: Nigeria. (2019). Digital economy diagnostic report. Washington, DC: World Bank. https:// www.worldbankgroup.org

Trade in the Digital Economy. (2020, March 12). Trade in the digital economy: A tralac guide. https://www.tralac.org/ publications/article/14437-trade-in-the-digital-economy-a-tralac-guide.html

UNCTAD. (2011). ASYCUDA world report 2011. Handbook of Global Customs Automation. United Nations Conference on Trade and Development. United Nations. https://unctad.org/system/files/official-document/dtlasycuda2011d1_ en.pdf

UNCTAD. (2013). Global supply chains: Trade and economic policies for developing countries. Policy issues in international trade and commodities study series no. 55. New York and Geneva.

UNCTAD. (2016). Activités de la CNUCED en faveur de l'Afrique [UNCTAD Activities in Favour of Africa]. UNCTAD: Geneva.

UNCTAD. (2019). Digital Economy Report. UNCTAD: Geneva. https://unctad.org/en/PublicationsLibrary/der2019 en.pdf

UNCTAD. (2020). Impact of the Covid-19 pandemic on trade and development. Transition to a new normal. Geneva. 
UNCTAD. (2020). Global Merchandise Trade Nowcast. UNCTAD. https:/unctad.org/system/files/official-document/ gdsdsimisc2020d3_en.pdf

UNECA. (2020). COVID-19 in Africa: protecting lives and economies. Addis Ababa: UNECA.

United Nations. (2020). Shared responsibility, global solidarity: Responding to the socio-economic impacts of COVID-19. United Nations.

WHO. (2021). WHO Coronavirus Disease (COVID-19) Dashboard. WHO. https://covid19.who.int/

World Bank. (2019). Data catalog. https:// datacatalog.worldbank.org/search/type/ dataset

World Bank Group. (2020). Nigeria in times of Covid-19: Laying foundations for a strong recovery. Nigeria Development Update.

World Bank Group and World Trade Organization. (2018). Trade and poverty reduction: New evidence of impacts in developing countries. Geneva: WTO.

World Economic Forum. (2020, May 19). Challenges and opportunities in the post-Covid-19 world. World Economic Forum. https://www.weforum.org/reports/post-covid-19-challenges-and-opportunities

World Trade Organisation. (2020, May 28). Trade-in services in the context of Covid-19. World Trade Organisation. https://www.wto.org/english/tratop_e/covid19_e/services_report_e.pdf

World Trade Organization. (2018). World trade statistical review 2018. Geneva: WTO. https://www.wto.org/english/res e/statis_e/wts2018_e/wts2018_e.pdf

World Trade Organization. (2020, April 8). Trade set to plunge as COVID-19 pandemic upends the global economy. WTO Press Release. https://www.wto.org/english/news_e/pres20_e/pr855_e.htm

World Trade Organization. (2021). Adapting to the digital trade era: Challenges and opportunities. Geneva. https:// www.wto.org/english/res_e/publications_e/adtera_e.htm

Zeufack, A. (2002). Export performance in Africa and Asia`s manufacturing: Evidence from firm-level data. Journal of African Economy, 10(3), 258-281. 